\title{
Development of a Mechanism for a Supply Chain Management System Formation
}

\author{
Evgeniya Tarasenko ${ }^{1}$, Dmitrii Karkh², Bakhtiyor Nasimov ${ }^{3}$, Venera Abbazova, ${ }^{2, *}$ \\ ${ }^{1}$ Orenburg Institute of Railway Transport - branch of SamGUPS, Orenburg, Russian Federation \\ ${ }^{2}$ Ural State University of Economics, Ekaterinburg, Russian Federation \\ ${ }^{3}$ Tashkent State University of Economics, Tashkent, Uzbekistan \\ *Corresponding author. Email: abbazova@usue.ru
}

\begin{abstract}
Diagnostics of logistics systems provides fast and efficient testing of railway transport enterprises in order to increase their sustainability by promptly eliminating bottlenecks and maximizing market opportunities. The value orientation of the management system involves the use of a logistic approach. The basis of the logistic approach is, on the one hand, the streams of consumer values, and on the other hand, the streams of products and services that form these values. The study is aimed at developing a methodological approach to the formation of a supply chain management system. System analysis, logical-structural methods, methods of classification and groupings were used as research methods. The research results make it possible to supplement the theory and methodology of supply chain management. The developed mechanism for the formation and development of the supply chain management system provides for the determination of the parameters of internal variables that make it possible to determine the competitiveness of a link in the supply chain; structuring the parameters of the internal variables of the supply chain.
\end{abstract}

Keywords: value stream, value stock, logistics, supply chain management, supply chain management system.

\section{INTRODUCTION}

The high level of competition in the market of transport and logistics services predetermines the relevance of developing new methods and principles for diagnosing logistics systems. Diagnostics of logistics systems provides fast and efficient testing of railway transport enterprises in order to increase their sustainability by promptly eliminating bottlenecks and maximizing market opportunities.

The logistic system is complex in structure, therefore, the diagnostics of this system is carried out in stages according to its constituent subsystems: the consumer value system, the resource supply system (chain), and the management system.

The tasks of designing, creating, as well as delivering values to end users of products and services are among the priority tasks of many enterprises, including railway transport.

If the end user, for some reason, did not receive value, the logistics system must take the necessary actions to rectify the situation.
Concepts such as "consumer value" or "usefulness of the product" are in direct proportion to the degree of satisfaction of the need with the product and the relative importance of the need. These definitions are subjective, evaluative indicators [9].

The value chain of the final product is called the sequence of operations to create the product itself (value) [1]. The creation, formation and smooth functioning of the value chain of the final product provides a process for managing the overall sequence of operations for creating a product (value) and information about product flows in all links of the value chain.

From the point of view of logistics as a concept of supply chain management, such definitions as "value stream" and "value stock" are of particular interest.

A value stream is a set of unique characteristics of objects and processes combined according to certain criteria, consistently felt by the consumer in space and time, depending on his material, mental or spiritual state $[2,9]$. 
The value stream can be called the defining, main, object of logistics. This logistics object is formed in conditions under which the consumer performs his usual functions of consumption, operation of resource flow objects.

The stock of value is a set of created or created unique characteristics of objects and processes, combined according to certain characteristics, which the consumer seeks to use in space and in time, depending on his material, mental or spiritual state $[3,9]$.

The formation and development of supply chain management systems should be focused on "the creation, communication, delivery and exchange of proposals that have value for customers, customers, partners and society as a whole" [4].

The value orientation of the management system involves the use of a logistic approach. The basis of the logistic approach is, on the one hand, the stream of consumer values, and on the other hand, the stream of products and services that form these values.

When forming a supply chain management system, one should take into account the specifics of the activities of enterprises. Transport enterprises, including railway transport enterprises, should focus not only on solving their internal tasks, but also on creating value for consumers of their products and services.

\section{MATERIALS AND METHODS}

When conducting the research and substantiating the recommendations, the works of domestic and foreign scientists in the field of economics, management, and logistics were used. System analysis, logical-structural methods, methods of classification and groupings were used as research methods.

The theoretical and methodological foundations of diagnostics of economic systems and control systems of various types are presented in the works of a number of foreign experts, such as A. Martinet [5], J.-P. Thibault [6], T. Kumar [7], N.N. Trenev [8] and others.

The object of this research is a focus enterprise. The initial stage in the development of a sequence for the formation of a supply chain management system is the identification of internal variables that determine the competitiveness of a link in the supply chain.

The authors propose to highlight the following internal variables:

1. Sources of competitiveness of the object of the economic system (preconditions (conditions) of development, potential (opportunities) of development)

2. The type of competitiveness factors of the object of the economic system (material and non-material factors)
The previously designated internal variables include (Fig. 1):

- $\quad$ material and technical base (hereinafter - MTB);

- $\quad$ staff (hereinafter - HR);

- goods (products and services) (hereinafter GPS);

- $\quad$ technology (hereinafter - T).

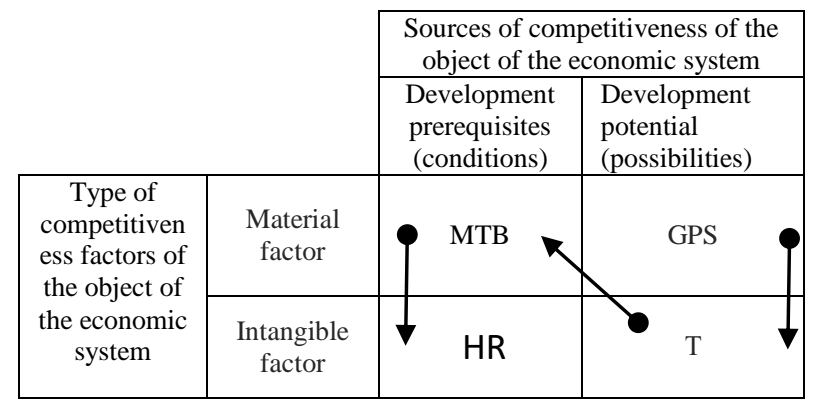

Figure 1 Internal variables that predetermine the competitiveness of a link in the supply chain.

It is advisable to determine the logical sequence of using the link of the logistic system of the internal variables identified by the authors. So, to ensure the uninterrupted production of products and the provision of services, technologies are needed, which, in turn, predetermine the availability of the necessary material and technical base, supported and serviced by qualified personnel at the link in the logistics chain.

As in any enterprise, an important condition for smooth operation is the full provision of the need for material resources (MTR). As you know, railway transport has an extremely high material consumption. A significant part of the material costs is operating costs.

For supply chains of material and technical resources, the main tasks are the most accurate planning of the material and technical support of territorial administration.

The value-based approach to management allows you to describe internal variables and evaluate them using the components of value stream management.

To assess the internal variables, the authors propose to distinguish the following components of value stream management:

- quantity (hereinafter - K);

- quality (hereinafter - Q);

- costs (hereinafter - Z);

- time (hereinafter $-\tau$ ).

It is advisable to determine and establish a set of parameters of internal variables that predetermine the 
competitiveness of a link in the supply chain - a focal enterprise (Table 1).

Table 1. The set of parameters of internal variables that predetermine the competitiveness of a link in the supply chain

\begin{tabular}{|c|c|c|c|c|}
\hline \multirow[b]{2}{*}{$\begin{array}{c}\text { Internal } \\
\text { variables in the } \\
\text { supply chain }\end{array}$} & \multicolumn{4}{|c|}{ Value parameters } \\
\hline & 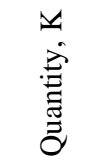 & 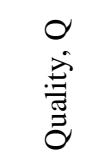 & $\begin{array}{l}N \\
\vec{b} \\
\dot{0}\end{array}$ & $\stackrel{+}{\Xi}$ \\
\hline $\begin{array}{l}\text { Material and } \\
\text { technical base } \\
\text { (MTB) }\end{array}$ & KMTB & QMTB & ZMTB & $\tau \mathrm{MTB}$ \\
\hline Personnel (HR) & KHR & QHR & ZHR & $\tau \mathrm{HR}$ \\
\hline $\begin{array}{l}\text { Product (GPS) } \\
\text { (products / } \\
\text { services) }\end{array}$ & KGPS & QGPS & ZGPS & $\tau$ GPS \\
\hline Technology (T) & KT & QT & ZT & $\tau \mathrm{T}$ \\
\hline
\end{tabular}

For example, to assess the personnel of an enterprise, such parameters are used as:

- number of KHR- payroll (all permanent and temporary employees who are registered at the enterprise) and attendance;

- quality QHR - the level of personnel qualification;

- costs ZHR - payroll fund;

- time $\tau$ HR - experience or work experience at the enterprise

\section{RESULTS AND DISCUSSION}

In many cases, it is advisable to carry out a multilevel structuring of the parameters of internal variables. An example of multilevel structuring of the parameters of one of the internal variables is presented in Table 2.

Table 2. Multilevel structuring of the parameters of the internal variable "goods (products / services)" in accordance with its range.

\begin{tabular}{|c|c|c|c|c|}
\hline \multirow[b]{2}{*}{$\begin{array}{l}\text { Assortment of goods } \\
\text { (products / services) }\end{array}$} & \multicolumn{4}{|c|}{ Goods (products / services) } \\
\hline & 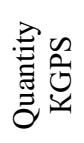 & 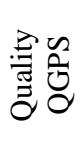 & 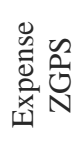 & 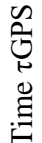 \\
\hline GPS1 & & & & \\
\hline GPS2 & & & & \\
\hline$\ldots$ & & & & \\
\hline GPSN & & & & \\
\hline
\end{tabular}

The basis of such a multi-level structuring is the classification of goods (products / services) of the link of the logistics chain - the focal enterprise, shown in Fig. 2.

The implementation of the value approach allows the end consumer of products and services to form future value based on its main characteristics and parameters, as well as to determine the conditions and requirements for the final link of the logistics chain. Thanks to the "upstream" principle, the final link of the logistics chain creates value and sets conditions and requirements for the previous link in the chain. The process of value formation and definition of requirements is carried out from the final to the initial link of the logistics chain.

\begin{tabular}{|c|c|c|c|}
\hline & \multicolumn{2}{|l|}{ Type of goods } \\
\hline & & $\begin{array}{l}\text { Products and } \\
\text { services }\end{array}$ & Service \\
\hline 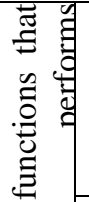 & 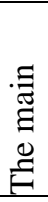 & $\begin{array}{l}\text { Material / } \\
\text { energy object }\end{array}$ & $\begin{array}{l}\text { Preparation of } \\
\text { production, } \\
\text { maintenance, repair }\end{array}$ \\
\hline 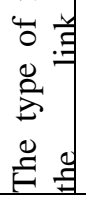 & 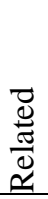 & $\begin{array}{l}\text { Packaging, } \\
\text { accessories, } \\
\text { spare parts, tools }\end{array}$ & $\begin{array}{l}\text { Promotion, } \\
\text { transportation / } \\
\text { storage, equipment, } \\
\text { training }\end{array}$ \\
\hline
\end{tabular}

Figure 2 Classification of goods (products / services) of the link of the supply chain - the focal enterprise.

Influencing the management system of the previous link in the logistics chain, the consumer value system significantly affects the stability of this link, as well as the stability of the previous links in the logistics chain.

When such conditions arise, it is advisable to reconcile the parameters of the internal variables of the link of the logistics chain - the focal enterprise according to the options "demand" and "supply".

The proposal allows you to assess the capabilities of a link in the supply chain to create customer value, and demand - to assess the state of the created customer value.

To solve this problem, it is proposed to use the matrix of coordination of the parameters of internal variables ("product (product / service)" and "technology"), presented in Table 3.

The process of coordinating the parameters of internal variables is recommended to be carried out in accordance with the sequence "goods (products and services) technology - material and technical base - personnel".

The initial stage of the process is pairwise matching of internal variables according to the "demand" option. For example, "product (products and services) is technology." At this stage, the parameters of quantity, quality, costs and time of the variable "goods (products and services") are reconciled with those similar parameters of the internal variable "technology", which are indicated in the requirement of the next link in the logistics chain [9].

In the same way, in pairs, the internal variables "technology" and "material and technical base", as well 
as "material and technical base" and personnel "are matched.

Table 3. Matrix of coordination of parameters of internal variables of a link of the logistics chain for the options "demand" (d) and "supply" (s).

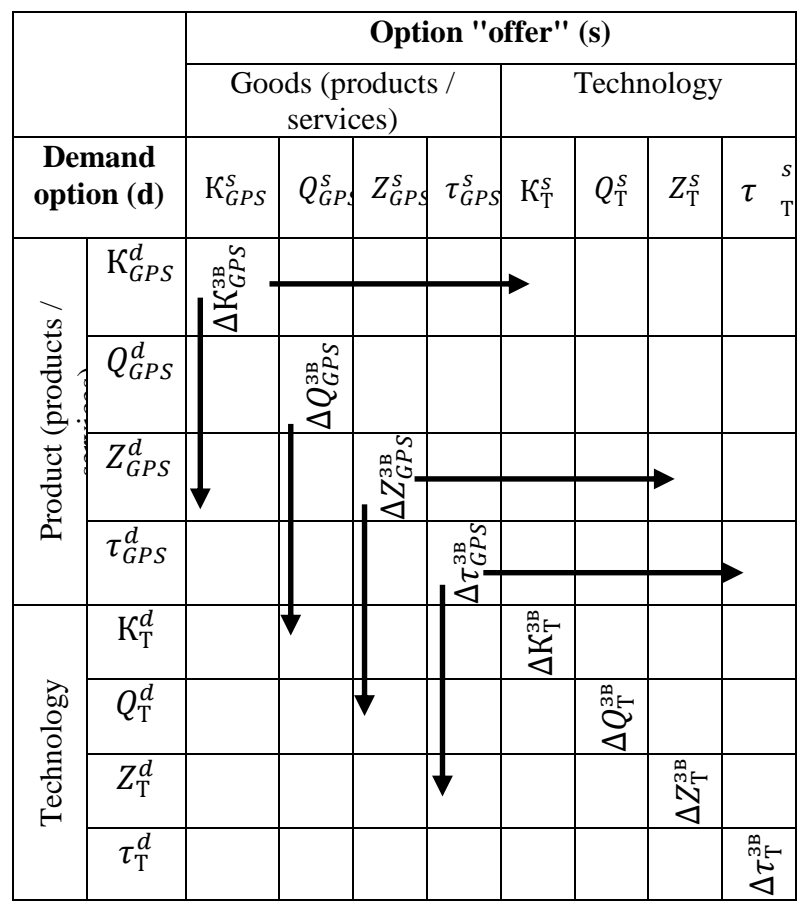

The next step in the negotiation process is the negotiation of internal variables for the "proposal" option. This raises the question of the possibility of the previous link in the chain to create value, which is necessary for the subsequent link in the logistics chain.

If the potential for value creation is not identified, there is a threat to the stability of this link, which, depending on the situation, will be supported by the three remaining subsystems of the management system.

The presence of the ability of the previous link in the chain to create value, entails the emergence of the problem of loading the internal variables of this link.

Under certain conditions, it is allowed to attract subcontractors who are able to take responsibility for the creation, formation and acquisition of value required for the subsequent link in the logistics chain.

\section{CONCLUSION}

The developed mechanism for the formation and development of the supply chain management system provides for the determination of the parameters of internal variables that make it possible to determine the competitiveness of a link in the supply chain; structuring the parameters of the internal variables of the supply chain; coordination of the parameters of the internal variables of the link of the supply chain according to the options "demand" and "supply".
The results of the study make it possible to supplement the theory and methodology of supply chain management, as well as to develop recommendations for increasing the competitiveness of chain links through better service to end consumers of products and services.

\section{REFERENCES}

[1] M. E. Porter, Competition in Global Industries. Boston: Harvard Business School Press, 1986.

[2] A.P. Tyapukhin, Classification of resellers and options for their use in supply chains, Management consulting, 4(76) (2015) pp. 94-106.

[3] A.P. Tyapukhin, On the concepts of "logistics" and "supply chain management", Logistics, 2 (2009) pp. 16-17.

[4] AMA. American Marketing Association, 2017. Definition ofMarket-ing. https://www.ama.org/AboutAMA/Pages/Definition -of-Marketing.aspx.

[5] A.C. Martinet, Diagnostic stratgique. Paris: Inter Editions, 1985, pp. 495.

[6] J.-P. Thibaut, Le diagnostic d'entreprise. Gujde pratique. Société d'édition et de diffusion pour la formation. Diffusion: les éditions d'organisation. 2eme'édition. Paris: SEDIOR, 1993, pp. 325.

[7] S.R. Singh, T. Kumar, Inventory Optimization in Efficient Supply Chain Management. International Journal of Computer Applications in Engineering Sciences, I(IV) (2011) pp. 428-433.

[8] N.N. Trenev, Enterprise and its structure: diagnostics, management, health improvement: textbook. Allowance, M.: PRIOR, 2002, pp. 240.

[9] A. P. Tyapukhin, M. Yu. Kolovertnova, E. A. Tarasenko, Supply Chain Management System: Essence And Methodical Approach To Creating, Bulletin Of Eurasian Science, 2 (2019) pp. 50. 